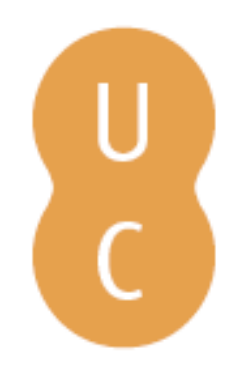

\title{
nombalina
}

\section{Calderón de la Barca y la adaptación dramática de las Etiópicas de Heliodoro}

Autor(es): $\quad$ Equihua, Rodolfo González

Publicado por: Imprensa da Universidade de Coimbra

URL

persistente: URI:http://hdl.handle.net/10316.2/42946

DOI: $\quad$ DOl:https://doi.org/10.14195/978-989-26-1439-7_3

Accessed : $\quad$ 26-Apr-2023 11:34:34

A navegação consulta e descarregamento dos títulos inseridos nas Bibliotecas Digitais UC Digitalis, UC Pombalina e UC Impactum, pressupõem a aceitação plena e sem reservas dos Termos e Condições de Uso destas Bibliotecas Digitais, disponíveis em https://digitalis.uc.pt/pt-pt/termos.

Conforme exposto nos referidos Termos e Condições de Uso, o descarregamento de títulos de acesso restrito requer uma licença válida de autorização devendo o utilizador aceder ao(s) documento(s) a partir de um endereço de IP da instituição detentora da supramencionada licença.

Ao utilizador é apenas permitido o descarregamento para uso pessoal, pelo que o emprego do(s) título(s) descarregado(s) para outro fim, designadamente comercial, carece de autorização do respetivo autor ou editor da obra.

Na medida em que todas as obras da UC Digitalis se encontram protegidas pelo Código do Direito de Autor e Direitos Conexos e demais legislação aplicável, toda a cópia, parcial ou total, deste documento, nos casos em que é legalmente admitida, deverá conter ou fazer-se acompanhar por este aviso.

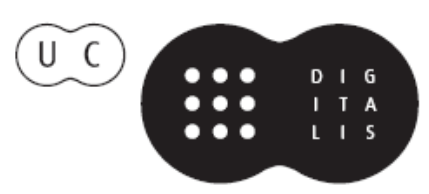




\section{Pervivencia del mundo clásico en la literatura:}

\section{tradición y relecturas}

\section{Aldo Rubén Pricco, Stella Maris Moro (coords.)}

IMPRENSA DA UNIVERSIDADE DE COIMBRA 


\title{
Calderón de la Barca y la adaptación dramática de $L A S$ ETIÓPICAS DE HELIODORO \\ (Calderón de la Barca and the dramatic adaptation of Heliodorus' Aethiopika)
}

\author{
Rodolfo González Equinua (rodolfoge@gmail.com) \\ Universidad Nacional Autónoma de México
}

\begin{abstract}
Resumen - Uno de los rasgos más destacados de las Etiópicas de Heliodoro es su teatralidad: no sólo porque contiene un buen número de metáforas escénicas y profusas descripciones de obras de arte sino también por la sucesión ininterrumpida de las peripecias que la articulan. No es extraño que Calderón se impusiera la difícil tarea de adaptar el potencial dramático de esta novela, cuya complejidad técnica y afán de sofisticación, o si se quiere retorización, se avenía muy bien con la poética y estética que él mismo cultivaba. Mi intención es analizar las soluciones argumentales que Calderón adoptó en el tránsito que va de las Etiópicas a Los hijos de la fortuna: Teágenes y Cariclea.

Palabras Clave: Novela griega, Heliodoro, Etiópicas, Calderón de la Barca, Pérez de Montalbán.
\end{abstract}

Abstract - One of the most notable features of Heliodorus' Aethiopika is its theatricality. Not only because it contains many stage-terms and profuse ekphrases but also by the ininterrumped succession of adventures that articulate it. It's no surprise that Calderon intend the difficult task of adapting the dramatic potential of this novel, whose technical complexity and desire of sophistication (rhetoricalization) conform well with the poetic and aesthetic that he cultivated. The purpose of this paper is to analyze the plot solutions that Calderon adopted in the transit from the Aetbiopika to Los bijos de la fortuna: Teágenes y Cariclea.

Keywords: Greek novel, Heliodorus, Aethiopika, Calderón de la Barca, Pérez de Montalbán.

El paso que va de las Etiópicas a Los hijos de la fortuna ha sido visto por unos como una distorsión ${ }^{1}$ y por otros como una rescritura ${ }^{2}$. Si optamos por la primera postura, asumimos que el resultado fue defectuoso, que la transmisión fue deficiente, que hubo un cisma. Si por la segunda, que la operación era en cierto modo innecesaria por reiterativa y por lo tanto una circunstancia agravante contra la poética y más precisamente, aunque suponga ciertas modificaciones, contra la imaginación, una tautología.

De ahí que adopte un término menos polémico como el de adaptación cuyo mecanismo consiste, como bien lo define Moliner (DUE) en la acepción que nos

\footnotetext{
${ }^{1}$ Rallo Grus 1983: 561-577.

${ }^{2}$ Gentilli 2010: 47-61.
} 
interesa, en modificar una obra literaria para que pueda ser transmitida por un medio distinto del pensado originariamente. En la acomodación, en el ajuste, en la tarea de amoldar una novela griega del siglo IV a una comedia española del XVII Calderón no partió de cero.

En el redescubrimiento de la novela griega antigua ${ }^{3}$ y más concretamente en el de Heliodoro, lo habían precedido en primera instancia, desde luego, el traductor, Fernando de Mena $(1587)^{4}$, que por cierto no la tradujo directamente del griego sino de una versión latina; el médico Alonso López Pinciano cuya Philosofía antigua poética $(1596)^{5}$, el único tratado sistemático tanto descriptivo como preceptivo de crítica literaria ${ }^{6}$, establecía que la Historia etiópica era un libro de épica amorosa en prosa y la encarecía al grado de sostener que "es de los poemas mejores que ha habido en el mundo" (2.331) y Heliodoro uno "de los más finos épicos que han hasta ahora escrito" (3.167). De ahí que no dude en situarlo a la par de Homero y Virgilio. Viniendo de la pluma de un "profesional", esta lectura caló a su vez en Cervantes quien en el prólogo de las Novelas ejemplares (1613) anticipa entre sus proyectos literarios Los trabajos de Persiles, un libro "que se atreve a competir con Heliodoro" y quien ya para el prólogo de la Segunda parte del Quijote (1615) declara que terminará de rematarlo, Deo volente, en cuatro meses?

De la adaptación terminológica de Alonso Pinciano se apropian tanto Cervantes en el Quijote (1. 47) cuando en la conversación sobre literatura caballeresca el canónigo dice al cura que "la épica también pueda escribirse en prosa como en verso"; como Lope de Vega cuando en La dama boba (1613) hace que la discreta y arrogante Nise explique a Celia, su criada, confusa y extrañada de que se refiera a Heliodoro como divino poeta griego pues hojeando su libro

${ }^{3}$ Como bien hacen notar Brioso Sánchez y Brioso Santos (2003: 431) los hispanistas suelen confundirse al llamarla novela bizantina cuando en sentido estricto esta denominación hace referencia, sí, a la novela griega pero no la escrita en la Antigüedad tardía sino en la Edad Media.

${ }^{4}$ A pesar de que hay una traducción reciente de las Etiópicas llevada a cabo por Emilio Crespo (1979), para este trabajo, por obvias razones, utilizo la de Fernando de Mena editada por F. López Estrada en 1954.

${ }^{5}$ Cito por la ed. en tres volúmenes de Carballo Picazo 1973.

${ }^{6}$ En el siglo XVI hubo muchas gramáticas del lenguaje poético aunque ninguna parangonable por su impronta y trascendencia a la del Pinciano. Están, por ejemplo, el Discurso sobre la poesía castellana (1575) de Gonzalo Argote de Molina; el Arte poética en romance castellano (1580) de Miguel Sánchez de Lima; el Arte poética (1592) de Juan Díaz Rengifo. El más hermoso, no obstante, fue el de las Anotaciones (1580) a las poesías de Garcilaso de Fernando de Herrera. Cf. Alatorre 2002: 244.

7 "El cual ha de ser -añade- o el más malo o el mejor que en nuestra lengua se haya compuesto, quiero decir de los de entretenimiento; y digo que me arrepiento de haber dicho el más malo, porque, según la opinión de mis amigos, ha de llegar al estremo de la bondad posible." Un año antes, en el Viaje al Parnaso (1614), 4.46-48, escribe "Yo estoy, cual decir suelen, puesto a pique / para dar a la estampa al gran Persiles, / con que mi nombre y mis obras multiplique". 
vio que no estaba escrito en verso, que también hay poesía en prosa y que la declare una historia amorosa digna de aplauso y de teatro ${ }^{8}$.

Juan Pérez de Montalbán, secuaz de Lope, sería el encargado de hacer realidad el deseo de Nise al ser el primero en llevar el asunto de las Etiópicas al teatro en una comedia que intituló Teágenes y Clariquea ${ }^{9}$, incluida en el Segundo tomo de las comedias publicada en Madrid en $1638^{10}$. Si Cervantes emula la técnica narrativa más notoria de las Etiópicas que es el comienzo in medias res, Montalbán, consciente de que verter la novela en el molde del teatro supone tomar algunas decisiones drásticas, opta por principio de cuentas en omitirlo y ordenar cronológicamente la acción. Tenía como atenuante que el propio Pinciano (3.207) afirmara que la doctrina de comenzar por el medio no era necesaria y quizá, como advertencia, la reacción indiferente de Celia, el aludido personaje de Lope, que se cansó con sólo mirar el principio de la novela ${ }^{11}$. El artificio griego que prepara el argumento para que no se dé a entender la trama sino hasta el quinto libro -las Etiópicas consta de diez-era un riesgo en la escena para la atención y paciencia de los espectadores. Enseguida viene el proceso de conferirle a la obra el acento convencional de una comedia de capa y espada, de una pieza dramática, según define el género Antonio Rey Hazas, "de asunto amoroso, tono distendido y final feliz matrimonial, basadas en el ingenio y el artificio del dramaturgo para conjugar coherentemente los más diversos lances de un cortejo, con sus escenas nocturnas, equívocos, cruces de damas y galanes, usurpación de identidades, confusiones, celos, duelos, etc."12. Una definición que, bien mirada, casi podría proceder de la lectura de cualquiera de las cinco novelas griegas de la Antigüedad que conservamos íntegras, las big five al decir de Susan Stephens ${ }^{13}$. En apariencia, más allá de las abundantes distracciones topográficas,

${ }^{8}$ Además, en la escena se nos dice que el libro de Heliodoro está impreso en cándido pergamino con muchas flores de oro, de ahí que Celia no quiera abrirlo ni tocarlo porque teme ensuciarlo. Nise asegura que un libro como el de Heliodoro bien amerita una edición de lujo.

${ }^{9}$ Valbuena Briones (1989: 338) explica que Cariclea es Clariquea en Montalbán porque ocurrió una pequeña metátesis fonética. No obstante, si nos atenemos a la extraña blancura de la heroína etíope no sería descabellado sugerir que Montalbán simplemente tradujo, adaptó el nombre haciéndolo derivar del adjetivo clara, la que está bañada y penetrada de luz (Diccionario de autoridades). Recordemos que el nombre griego de Cariclea está compuesto por charis, gracia, y kleos, gloria, es decir, la famosa, la afamada, por su gracia.

${ }_{10}$ Claudia Demattè, quien dirige el proyecto "Un autor madrileño recuperado: Juan Pérez de Montalbán”, prepara una edición crítica de este segundo tomo para la editorial Reichenberger.

${ }^{11}$ Menéndez Pelayo (2008: 17) en la misma tónica que la criada de Nise ("miré el principio y cansóme") afirma al referirse a la novela de Heliodoro que "no puede ser un libro vulgar el que ha logrado tales admiradores y panegiristas, pero es seguramente un libro de muy cansada lectura."

${ }^{12}$ En Alcalá-Zamora y Díez Borque 2000: 333.

${ }^{13}$ Quéreas y Calírroe de Caritón de Afrodisias (ca. 100), las Efesíacas de Jenofonte de Éfeso (ca. 120-150), Leucipa y Clitofonte de Aquiles Tacio; Dafnis y Cloe de Longo (ambas de la 2a. mitad del s. II), y las Etiópicas de Heliodoro (s. IV). Cf. Stephens 1995: 4. 
los anacronismos deliberados y de las atribuciones erróneas, casi todas las soluciones que adoptó Montalbán nos parecerían arbitrarias, pensamos que el Pinciano las encontraría carentes de imitación y de verosimilitud, más propias de un disparate que de una fábula hecha y derecha. No obstante, perdemos de vista que todas, por paradójico que parezca, hasta cierto punto, estaban encaminadas para que su Teágenes y Clariquea adquiriera una mayor unidad y secuencia.

Según Claudia Demattè ${ }^{14}$, la mayor originalidad de Montalbán radica en anudar aún más el enredo de Heliodoro porque hace de Teágenes otro expósito: resulta que era hijo de Orontes, de la Grecia dueño, y que su madrastra-la madre había muerto en el parto- tuvo a bien deshacerse del heredero, del príncipe de Tesalia, en la ribera del mar Jonio. Un ejemplo de cómo la abrumadora fantasía del dramaturgo no tenía límites. Sí, leyó a Heliodoro pero parece que se impuso de inmediato la tarea de olvidarlo y obrar como el autor que cavila la imprecisa imagen anterior de un texto antes de ponerlo por escrito. Oróndates, en las Etiópicas era un sátrapa persa y precisamente uno de los antagonistas de la pareja. No obstante, la rara y excéntrica genealogía de Montalbán hubiera hecho sonreír a Heliodoro quien, por su parte, había hecho de Teágenes un eniane descendiente de Aquiles. Históricamente los enianes fueron un colectivo minoritario. Tienen una discretísima presencia en el catálogo de las naves (Il. 2.749). La literatura del periodo clásico sólo los menciona ocasionalmente y Estrabón ${ }^{15}$ nos informa que

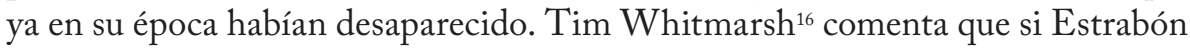
encontraba demasiado oscuro el origen de un pueblo como para mencionarlo en su obra es porque en realidad lo era y conjetura, quizá con acierto, que la única razón que Heliodoro tenía para hacer de Teágenes un eniane y, a su vez, un tesalio, es provocar una disparidad irónica entre la oscuridad del gentilicio y la desproporcionada ascendencia que se adjudica.

Otra aportación de Montalbán fue la incrustación de la acción cómica con los personajes de Frisón y Marfisa, criados de Teágenes y Clariquea respectivamente. Calderón, a diferencia de Montalbán que lo convierte en príncipe de China y en un pretendiente más de la protagonista, sí supo ver-de ahí el remozamiento de esta línea argumental- que el ateniense Cnemón de Heliodoro era en quien recaía la vis cómica, la impostura dramática de los dos primeros libros de la novela. En efecto, en las Etiópicas, el relato secundario de Cnemón tiene la función de informar y estructurar mediante antítesis, como ocurre con la figura del gracioso en las comedias de capa y espada ${ }^{17}$, el amor idealizado de los protagonistas. El amor ordinario de Cnemón y Tisbe y el noble de Teágenes y Cariclea forman un marco de valores morales cuya

\footnotetext{
${ }^{14}$ 2012: 373.

${ }_{15}$ Geographica 1. 2. 21; 9. 4. 11; 9. 5. 22.

16 1998: 103-104.

${ }^{17}$ Arango 1980: 377-78.
} 
expresión y cuyo reforzamiento es, en palabras de J. R. Morgan ${ }^{18}$, la raison d'être de la fábula.

Dentro de las curiosas innovaciones llevadas a cabo por Montalbán que ameritan figurar como ejemplos de su libre imaginación, de su imitación activa, quiero destacar el episodio con el que da inicio la jornada tercera y en donde Teágenes pronuncia ante Eumenes, rey de Egipto, un relato de sus tribulaciones que, aunque no lo formula como mendaz, está construido a partir de los relatos mendaces presentes en la novela de Heliodoro. En las Etiópicas la encargada de urdirlos es Cariclea ${ }^{19}$, a quien se compara por sus dotes persuasivas, con una sirena ( en presentarla como una consumada compositora de relatos ficticios, una sofista. Calderón, en cambio, sí conserva este rasgo, a pesar de que nos diga que "crióse / sin maestros en la desierta / prisión de pobre alquería" ${ }^{1}$, y hace que Teágenes ante el despliegue inventivo de la heroína, ante su industria para fingir exclame “¿Dónde irán a parar, ¡cielos!, / tan bien compuestas ficciones?” (430). Montalbán, en cambio, hace que Teágenes adopte como dos episodios más de sus aventuras, uno entresacado no de las Etiópicas sino de la Ulyxea-el nombre con que los escritores de los Siglos de Oro denominaban la Odisea ${ }^{22}$. Es decir, Montalbán, en pleno fervor compositivo, bien pudo confundir adrede ambas obras, después de todo si la estructura de las Etiópicas remitía a la de la Odisea, qué más daba remitirse a el precursor. Es probable incluso que ni siquiera le hiciera falta leerla, la trama de la épica, con su cadena de incidentes, estaba en la memoria de todos. Por eso sitúa a sus protagonistas en un escenario homérico por otra parte imposible: en la cueva de los lotófagos, "atroces Polifemos", a los que, como vemos, confunde o empalma con los cíclopes. El segundo episodio y en otro escenario fantástico, esta vez expropiado de la obra de Cervantes, contemporáneo suyo que será después igualmente precursor de tantos otros libros, Teágenes refiere que dieron en el mar que se hiela y que impidió que su embarcación prosiguiera. Montalbán leyó el Persiles (1617) y debió gustarle como peripecia el mar Glacial (2.16) donde la nave de Periandro queda empedrada y decide sin más incorporarlo en el relato de su personaje ${ }^{23}$. Homero doce siglos

${ }^{18}$ Morgan 1989: 107.

${ }^{19}$ Cuando Teágenes se muestra mendaz ante Cibele (Hld. 7.13) no es por iniciativa propia sino gracias al guión que previamente había urdido Cariclea.

${ }_{20}^{20}$ Pernot 1992: 43-51.

${ }^{21}$ Cito por número de página la edición de D.W.Cruickshank 2007:384. Heliodoro (2.33.3), por su parte, nos dice, que Cariclea aprendió de inmediato la lengua griega de Caricles.

${ }^{22}$ Guichard 2006: 49-72.

${ }^{23}$ Leemos así en la jornada tercera: "Bien estuvimos más de veinte Auroras / esperando por horas, / que Apolo desleyera / la superficie de la blanda cera, / que fue zurciendo el yelo, / mas viendo pocas señas en el cielo / de desenmarañar la riza estambre, y viendo que el hambre / llegaba horrible, y fea, / hasta roer las jarcias, y la brea, / el mar dexamos todos...". 
antes y Cervantes doce después comenzaron así a formar parte ya no sólo de la biografía de Heliodoro sino a escribir nuevos episodios de su fábula.

Pero a propósito de los orígenes de Teágenes, no es precisamente, como dice Demattè, que Montalbán haya enredado más la fábula sino que vislumbró una solución para simplificarla que apenas esbozó de forma muy descuidada y que sólo Calderón, un escritor harto más complejo y con mayor oficio que Montalbán, con el que por otra parte había colaborado en tres $\operatorname{comedias}^{24}$, sí supo aprovechar: la construcción de la fábula de Teágenes, el hijo de la Fortuna. La agnición principal que en Heliodoro era la de Cariclea ante sus padres etíopes, aquí el dramaturgo tiene a bien doblarla, en una de sus características y elaboradas correlaciones, y hace que Caricles sea el padre de Teágenes, el hijo que le fuera robado tiempo atrás en el saqueo del "claustral olimpo" de Apolo en Delfos -donde las sacerdotisas en traje de ninfas tienen claustros-, por parte de los tesalios. Motivo por el que la comedia da inicio con el pregón que anuncia el sacrificio quinquenal que los tesalios, una vez sellada la paz con los delfios, ofrecen a modo de desagravio. En las Etiópicas (2.29.32), en cambio, se nos dice que este sacerdote había tenido una única hija que murió la noche de bodas a causa de un incendio y que poco después, de pesar, muere la madre; encadenamiento de infortunios que lo orillan a exiliarse y a encontrarse en Catadupos, la primera catarata que formaba la frontera, la raya como dice Calderón, entre Egipto y Etiopía, con el gimnosofista Sisimitres quien, a su vez y a manera de una compensación providencial, le da en adopción a una niña de extraordinaria y divina belleza que no es otra sino Cariclea.

Cierto, la versión de Calderón está más apegada a la novela, conserva los aspectos y episodios fundamentales del argumento y los personajes principales. Al contrario de lo que ocurre con las comedias de tema mitológico, en lugar de los muchos materiales de relleno y de los muchos alargamientos, sus esfuerzos técnicos debían centrarse en la tarea de abreviar e intensificar una novela cuya extensión la hacía de entrada irrepresentable. La lectura de Montalbán con sus aciertos y yerros fue un buen punto de partida para regresar a la lectura de la novela y volver con una adaptación más convincente y acabada.

Si para Calderón la pintura llega a ser un elemento importante de la acción dramática, piénsese por ejemplo en Darlo todo y no dar nada y El pintor de su deshonra y en la petición-desconozco si cumplida- de E. R. Curtius de hacer un index pictorius del teatro calderoniano, que registrase las muchas metáforas y conceptos que el dramaturgo tomó de la plástica ${ }^{25}$, entonces la fábula de los siglos de Heliodoro le suministraría un argumento afín a su estética manierista. Recordemos que el asunto capital de las Etiópicas es la identidad de Cariclea

\footnotetext{
${ }^{24}$ Cf. Wilson, Moir 1974 y Cruickshank 2009: 50.

${ }^{25}$ Curtius 1998 (1ª ed. en alemán 1948): 776-790.
} 
y su problemática concepción que hace exclamar a su padre, en la versión de Fernando de Mena, "porque siendo entrambos Ethyopes, ¿cómo puede caer en

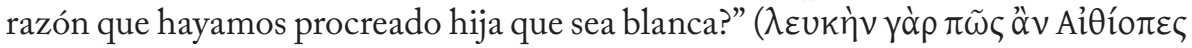

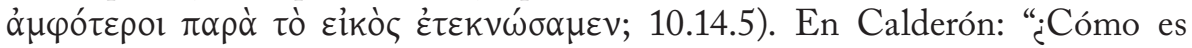
posible que sea / natural la que contraria / tanto es a la color nuestra?” (462). O Idaspes, aquí en lugar de rey un noble sátrapa de Etiopía (356):
Si en Etiopía nacida, dije, donde los estivos rayos del sol más ardientes tiñen la tez de sus hijos, ¿cómo tan blanca? ¿De cuándo acá en el mundo se ha visto que en los nidos de los cuervos se alimenten los armiños?

La explicación no parte de un principio biológico sino artístico que expresa la eterna dialéctica entre arte y naturaleza y de este modo Heliodoro monta una escena de reconocimiento inaudita ${ }^{26}$ : hace que el gimnosofista Sisimitres zanje el problema, la quaestio, bajando el cuadro ( $\varepsilon i k \omega \omega v)$ de Andrómeda para ponerlo al lado de Cariclea y que todos comprueben la cabal identidad entre ambas. La vida había imitado, no metafórica, sino literalmente, al arte.

He aquí que por haber fijado en aquel su mirada al momento de la concepción la potente imaginación (la phantasia) de Persina, "la imaginativa fuerza de la aprehensión” diría Calderón, impregnó, preñó de los rasgos de Andrómeda a su hija. Calderón, por boca de Hidaspes, añade: "Y más cuando, para mayor consecuencia, / el concepto parecido / tanto es a la imagen bella / de Andrómeda, que es quien siempre / retratada está en tu idea” (463). E1 Diccionario de autoridades nos dice que en la pintura un concepto es "la idea o dibujo intencional que forma el pintor que inventa, antes de llegarlo a delinear: y así se llama bueno o mal concepto, según es el capricho de lo inventado”. En efecto, al principio de la jornada tercera en la que al correrse una cortina "vese de diosa un retrato de Cariclea", Persina dice (436):

${ }^{26}$ Las ficciones de Edgar Allan Poe (The oval portrait) y de Oscar Wilde (The picture of Dorian Grey) tendrían en Heliodoro un digno precursor. 


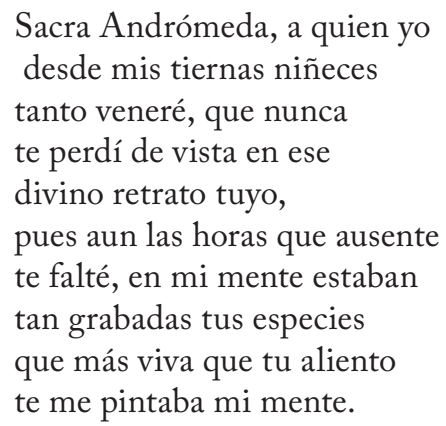

Antes, en la jornada segunda, a propósito del episodio sobre el mal de ojo, la baskania, la fascinación, que aqueja a Cariclea, Calasiris argumenta a un incrédulo Cariclés que se resiste a creer en el mal de ojo (382):
Eso fuera negar a la fantasía que varios efectos tenga --de que vemos divinas y humanas historias llenas están de monstruosidades, si no de aprensiva fuerza, de vehemente estimativa, que aquello que mira engendra. El parecerse los hijos a los padres, ¿no es presencia de objeto? El no parecerse, ¿no es diversión de la idea puesta en otra cosa, a quien quizá después se parezcan?

Vemos cómo Calderón funde los dos episodios, siembra hábilmente este principio que se cumple en la escena de reconocimiento y recoge además la tesis principal de la novela de Heliodoro expresado por boca del sabio Calasiris de que "la naturaleza también puede con arte ser vencida"

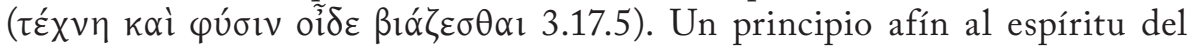
dramaturgo.

Dentro de las especies de reconocimiento ajenas al arte, es decir, que no derivan de una peripecia, Aristóteles (Po. 1454b) distingue las connaturales (symphyta) y las adquiridas, y dentro de éstas, a su vez, las que están en el cuerpo y las que están fuera de él. Heliodoro aporta como prueba congénita, una marca de nacimiento, de ahí que Sisimitres ordene a Cariclea que descubra su brazo izquierdo para que muestre el lunar que tuviera la niña expósita: "Desnudose Chariclea el brazo siniestro, y mostroles la señal, que como un cerco de ébano, 


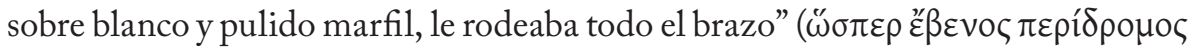

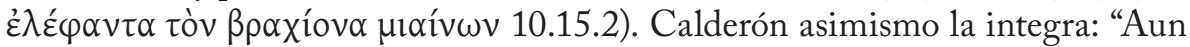
esta seña / del negro lunar afirma / más que toda la evidencia / de igual prodigio" (464).

Heliodoro también se vio seducido -quién no- por la metáfora del gran teatro del mundo. El narrador de su historia se distingue por el uso recurrente de símiles y metáforas concernientes al teatro, que operan como comentarios literarios de la trama y que convierten al lector en espectador. De ahí que nos diga que el pueblo etíope "aunque no entendía las más de las palabras que se decían, todavía conjeturaba lo que era, por las cosas que habían pasado de Chariclea, y también por ventura, por alguna divina inspiración, que hizo que todo aquesto cayese tan maravillosamente: como en alguna escena, o teatro o para que viniesen en cumplido conocimiento de la verdad" (10.38.3). Como escritor erudito antes o después de intuir el encanto de la metáfora pudo leerla en Platón quien afirmaba que el hombre es un juguete animado de $\operatorname{dios}^{27}$ o bien la expresada en boca de Sócrates en el Filebo de que "en las lamentaciones y tragedias, no sólo del teatro, sino en la tragedia y comedia de la vida humana, el placer va mezclado con el dolor" ${ }^{28}$. Calderón, por su parte, hace decir a su protagonista, a propósito de lo que en la novela de Heliodoro fuera la celebrada descripción con la que inicia su relato del paisaje después de la batalla, la llamada puzzling scene ${ }^{29}$, por la cuidada plasticidad con que nos introduce en la historia, lo siguiente: “Qué teatro fue en la más trágica escena de cuantas representó la deidad de la Fortuna más horrible?” (406). Y que Persina cuando hace su relato exclame, a la manera de Segismundo: “ $\mathrm{O}$ h tú, infeliz hermosura, / que fábula de los siglos, / sin ser delito, naciste / para parecer delito" (350).

A veces en unos cuantos versos Calderón hace la síntesis de episodios completos. Heliodoro hace un excurso sobre el tópico de las fuentes del Nilo, Calderón la llama hidra de cristal por sus siete desembocaduras. ¿Pudo saber que el escritor bizantino del siglo XI, Miguel Pselo, llamó a la novela de Heliodoro

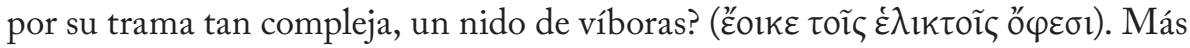
tarde, Calderón se refiere al río como un "centauro indiano" porque nace "bozal para morir gitano” (362), es decir, un río que procede del África negra para morir en Egipto. Y he aquí que la función de este río en la novela además de ser una plantilla, un mapa narrativo, precisamente es la de constituirse una figura

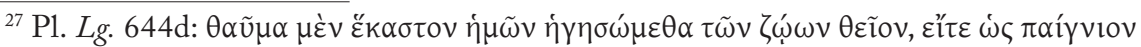

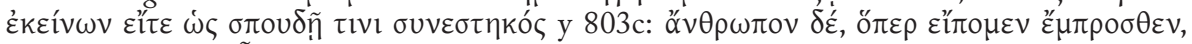

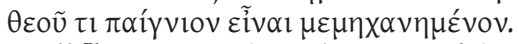

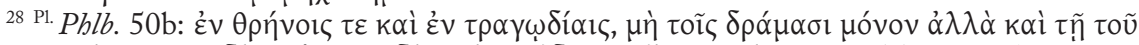

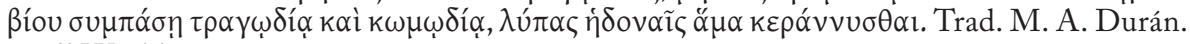

${ }^{29}$ Winkler 2000-2001: 161-184. 
más, de las muchas con las que juega la novela, de los problemáticos orígenes de Cariclea $^{30}$.

Un ejemplo final, las Etiópicas ha sido considerada con razón una refutación geográfica de los márgenes y el centro del helenismo. Prueba de ello sería la elección por parte de Heliodoro del término mixellen, mitad griego (9.24.2) ${ }^{31}$, en menoscabo de mixobarbaros, mitad bárbaro. Calderón intuyendo que este término para aludir al mestizaje es importante para la novela lo adopta y hace decir a Jebnón: "que soy griego por la vida / y gitano por el alma; y grieguigitano, ya se ve si es la mescolanza para no ser embustero" (366).

El método que empleó Calderón en la adaptación de la novela de Heliodoro no consistió en conocer bien el griego de la koine con el que escribió Heliodoro, ni en imaginarse ser un fenicio de Émesa, ni en suprimir de un plumazo los más de diez siglos que lo separaban de su modelo. Consistió en ser simplemente un dramaturgo de la España del XVII, lector de Alonso Pinciano, Cervantes, Montalbán y de la historia de los dos leales amantes Teágenes y Cariclea, escrita por Heliodoro y traducida por Fernando de Mena al español del siglo XVI.

\footnotetext{
${ }^{30}$ Elmer 2008: 114-133.

${ }^{31}$ Fernando de Mena traduce: "el qual por parte de uno de sus padres era de nacimiento griego".
} 


\section{Bibliografía}

Alatorre, A. (2002), Los 1001 años de la lengua española. México: Fondo de Cultura Económica.

Alcalá-Zamora, J., Díez Borque, J. M. (eds.) (2000), Calderón de la Barca. Obras maestras. Madrid: Editorial Castalia.

Arango, M. A. (1980), "El gracioso, sus cualidades y rasgos distintivos en cuatro dramaturgos del siglo XVII: Lope de Vega, Tirso de Molina, Juan Ruiz de Alarcón y Pedro Calderón de la Barca”, Thesaurus 35-2: 377-378.

Brioso Sánchez, M., Brioso Santos, H. (2004), "De nuevo sobre Cervantes y Heliodoro", Cervantes: Bulletin of the Cervantes Society of America 23. 2: 297-341.

Carballo Picazo, A. (ed.) (1973), Alonso López Pinciano. Philosophia antigua poética. Madrid: Consejo Superior de Investigaciones Científicas.

Cruickshank, D.W. (ed.) (2007), Calderón de la Barca. Comedias III. Madrid: Fundación José Antonio de Castro.

Cruickshank, D.W. (2009), Don Pedro Calderón. Cambridge: Cambridge University Press.

Curtius, E. R. (1998), "La teoría del arte en Calderón y las artes liberales", in Literatura europea y Edad Media latina. México (1 a ed. en alemán 1948), Fondo de Cultura Económica: 776-790.

Demattè, C. (2012), "Ecos cervantinos en las obras de Juan Pérez de Montalbán”, eHumanista/Cervantes 1: 366-380.

Elmer, D. F. (2008), “Heliodoro's 'Sources': Intertextuality, Paternity, and the Nile River in the Aithiopika", TAPA 138: 411-450.

Gentilli, L. (2010), "Calderón e la riscrittura delle Etiopiche di Eliodoro", Il confronto letterario 53: 47-61.

Guichard, L.A. (2006), "La Ulixea de Gonzalo Pérez y las traducciones latinas del género", in Taylor, B., Coroleu, A. (eds.), Latin and Vernacular in Renaissance Iberia II: Translations and Adaptations. Manchester, Manchester University Press: 49-72.

López Estrada, F. (ed.) (1954), Heliodoro. Historia etiópica de los amores de Teágenes y Cariclea, traducida en romance por Fernando de Mena. Madrid: Aldus.

Morgan, J. R. (1989), “The Story of Knemon in Heliodoros' Aithiopika”, JHS 109: 259-285.

Pernot, L. (1992), "Chariclée la sirène”, in Baslez, M.-F., Hoffmann, P., Trédé, M. (eds.), Le Monde du Roman Grec. Paris, Presses de L'École Normale Supérieure: 43-51.

Rallo Grus, A. (1983), “La distorsión dramática de un texto narrativo: 'Los hijos 
de la fortuna: Teágenes y Cariclea' de Calderón”, in García Lorenzo, L. (ed.), Actas del Congreso Internacional sobre Calderón y el teatro español del Siglo de Oro. Vol. I. Madrid, Consejo Superior de Investigaciones Científicas: 561-577.

Rey Hazas, A. (2000), "Comedias de enredo”, en Alcalá-Zamora, J., Díez Borque, J. M. (eds.), Calderón de la Barca. Obras maestras. Madrid, Editorial Castalia: 333-335.

Stephens, S. (1995), Ancient Greek Novels. The Fragments. Princeton: Princeton University Press.

Valbuena-Briones, A. (1989), "La undécima epístola de López Pinciano y la libertad creadora de Pérez de Montalbán”, Rilce 5-2: 333-343.

Whitmarsh, T. (1998), "Heliodorus and the Genealogy of Hellenism", in Hunter, R. (ed.), Studies in Heliodorus. Cambridge Philological Society: 93-124.

Wilson E. M., Moir, D. (eds.) (1974), Historia de la literatura española. Siglo de Oro: teatro (1492-1700). Barcelona: Ariel.

Winkler, M. (2002), "The cinematic nature of the opening scene of Heliodoros' Aithiopika”, AncNarr 1: 161-184. 